\title{
Density and Population Structure of Globally Vulnerable and Endangered Trees in Chennai Metropolitan City, India
}

\author{
M. Udayakumar ${ }^{1, *}$, A. Selvam ${ }^{1}$, T. Sekar ${ }^{2}$ \\ ${ }^{1}$ Department of Plant Science, Manonmaniam Sundaranar University, Tirunelveli, Tamil Nadu, India \\ ${ }^{2} \mathrm{PG}$ and Research Department of Botany, Pachaiyappa's College, Chennai, Tamil Nadu, India
}

Received March 19, 2020; Revised April 13, 2020; Accepted April 27, 2020

Copyright $\mathrm{O} 2020$ by authors, all rights reserved. Authors agree that this article remains permanently open access under the terms of the Creative Commons Attribution License 4.0 International License

\begin{abstract}
A quantitative floristic study was conducted in Chennai metropolitan city (CMC), Tamil Nadu, India to estimate density and population structure of trees categorized as vulnerable and endangered by International Union for Conservation of Nature and Natural Resources (IUCN) red-list. A total of one hundred 1 -ha $(100 \mathrm{~m} \times 100$ m) square plots were randomly laid to estimate density and species richness of threatened trees in study area. All trees $\geq 10 \mathrm{~cm}$ girth at breast height (gbh) were recorded, and identified up to species level on the field with the aid of regional floras and checklists. Six different land uses were recognised. In total, 10426 trees belonging to 99 species, 36 families and 86 genera were recorded. Of six land use categories, riverbanks had highest tree density (150.08 \pm 21.02 trees $\left.\mathrm{ha}^{-1}\right)$ followed by parks $(138.86 \pm 29.08$ trees $\left.\mathrm{ha}^{-1}\right)$ and institutional areas $\left(98.77 \pm 4.48\right.$ trees $\left.\mathrm{ha}^{-1}\right)$. In total, 1272 IUCN red-listed trees belonged to six families and eight genera were enumerated. Among land uses, educational institutions had largest number of threatened trees (374 individuals) followed by parks (327 individuals) and residential areas (228 individuals). We find Chennai's urban forests as home for seven vulnerable and three endangered tree species. This study reveals density and population structure of threatened trees growing in $\mathrm{CMC}$, India.
\end{abstract}

Keywords Endangered Tree Species, South India, Threatened Species, Urban Forest, Vulnerable Tree Species

\section{Introduction}

Urban forests serve aesthetic, ecological, health, psychological and social functions [1]. They form a considerable amount of nation's total tree cover [2]. In addition, urban forests provide habitat for plants and animals [3]. Frequently, the species richness of urban forests is greater than it is in rural areas [4-8]. Further, urban forests provide niches to endangered species [9]. Besides, urbanized areas also harbor a large number of threatened species [10-13]. Interestingly, even a small green space serves as a habitat for native flora and fauna [14]. Information on density and species richness of threatened species is one of the basic needs to assess conservation values of urban forests and trees [15]. Promoting and preserving biota within urban forests is believed to decelerate the uncontrollable biodiversity loss [2]. Baseline data such as density, diversity and species richness of plant and animal species are scarce for many Indian cities including Chennai. Information on these lines could aid in the preparation of conservation measures that protect and preserve species from damages. Only a limited number of studies have concentrated on urban biodiversity in Chennai Metropolitan City (CMC) [14, 16, 17]. Moreover, information on threatened trees of CMC is lacking. Thus, the present study was planned to fill this gap, and to assess density and species richness and population structure of globally vulnerable and endangered tree species in CMC.

\section{Methods}

\subsection{Study Area}

Chennai is one of the four metropolitan cities of the Indian sub-continent. The city is the capital of Tamil Nadu state and has $174 \mathrm{~km}^{2}$ of geographical area. Climate of the city is tropical-humid. The mean maximum and minimum temperature and rainfall are $37^{\circ} \mathrm{C}$ and $24^{\circ} \mathrm{C}$, and 1200 and 
$1300 \mathrm{~mm}$, respectively [18]. The city serves as home for 6.4 million people [19]. The city has Bay of Bengal as its eastern border and Thiruvallur and Kanchipuram districts as its northern, southern and western boundaries.

\subsection{Field Survey}

The entire area of CMC is sub-gridded into hectares by using ArcGIS 9.3 tool. Among sub-grids 100 study plots (one ha each) were selected with random table for tree density enumeration. A total of one hundred 1-ha (100 m x $100 \mathrm{~m}$ ) square plots were laid to reveal density of IUCN's
Red-listed trees in CMC (Figure 1). Study area comprises of residential areas, urban parks, educational institutions, roads, riverbanks and government offices (Table 1). All trees $\geq 10 \mathrm{~cm}$ girth at breast height were counted. All the encountered trees were identified to species level in the field with the help of available field guides, floras and checklists $[14,16,20]$. Voucher specimens were deposited at Pachaiyappa's College Herbarium, Chennai (PCHC). Status of threatened species was recorded with the help of IUCN Red List's website [21].

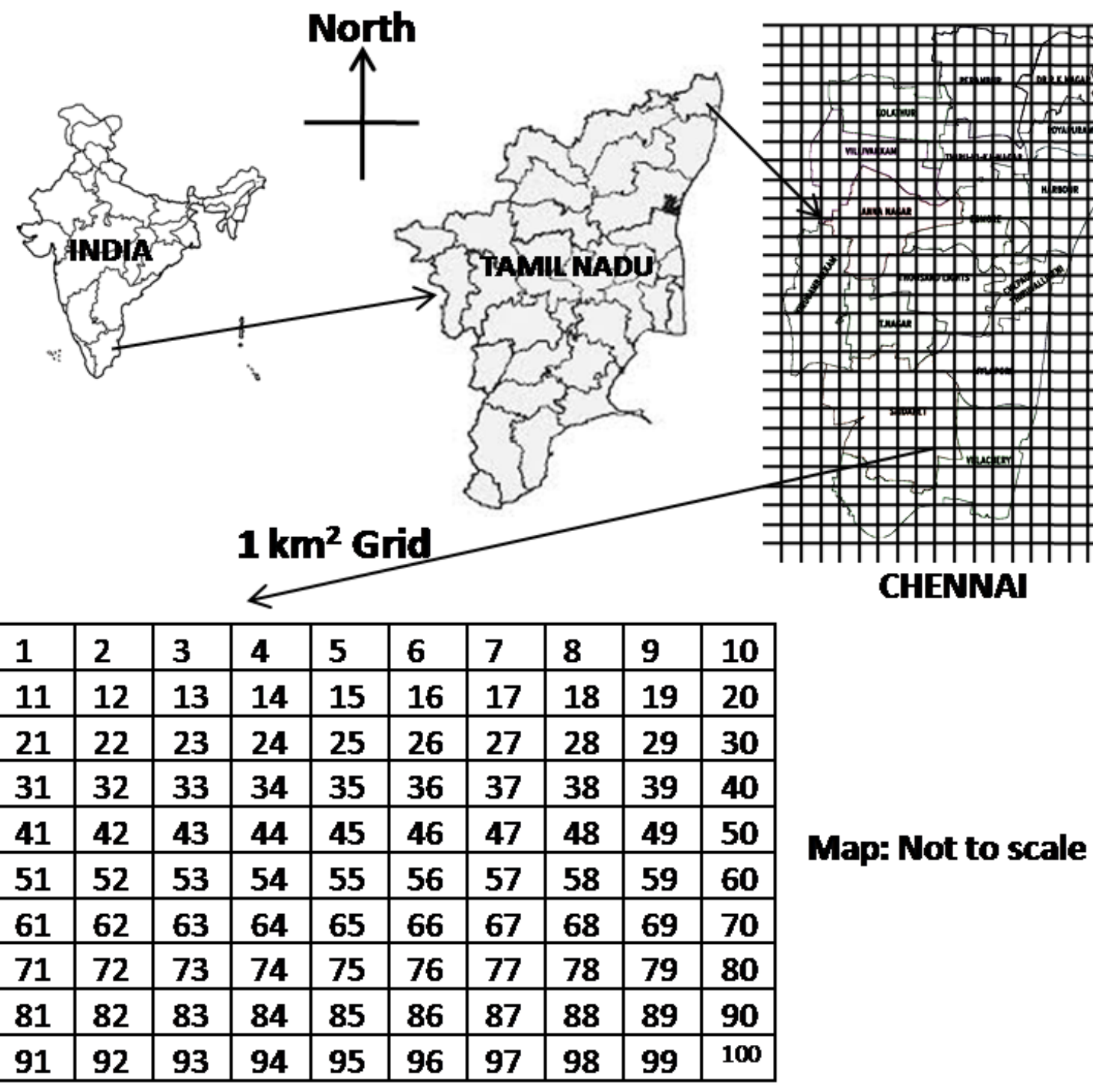

Figure 1. Map of Chennai metropolitan city wherein tree diversity study conducted 
Table 1. Land use types and area covered to record threatened trees in study area

\begin{tabular}{|c|c|}
\hline Land use type & Area covered (ha) \\
\hline Educational institutions & 19.532 \\
\hline Riverbanks & 13.234 \\
\hline Parks & 21.512 \\
\hline Road sides & 16.112 \\
\hline Residential areas & 20.511 \\
\hline Government offices & 9.099 \\
\hline Total & 100.000 \\
\hline
\end{tabular}

\subsection{Diversity Indices}

The Shannon diversity $(H)$ and equitability $\left(E_{H}\right)$ indices were computed for all the sample plots together (total area $=100$ ha) [22].

$$
H=-\sum_{i=I}^{S} P i \ln P i
$$

where $H$ is known as Shannon diversity index; $P i$ termed as a fraction of the whole population made up of species $i ; S$ recognized as numbers of species encountered; $\sum$ is the total number of species from 1 to $S$.

Shannon equitability index $\left(E_{H}\right)$ computed by dividing $H$ by $H_{\max }\left(H_{\max }=\ln S\right) . E_{H}=H / H_{\max }=H / H_{\max }=H / \ln S$. Species richness of study area was calculated directly by summing the number of species encountered in each 1-ha study plot. Similarly, tree density of study area also calculated directly by totaling the number of individuals recorded in each study plot.

\section{Results and Discussion}

\subsection{Species, Genera and Family Richness}

On the whole, during January to December, 2012 we recorded 10426 trees in 100 ha study area. Ninety nine tree species belonging to 36 families and 86 genera were recorded. The family Fabaceae represented with large number of species (22 species) followed by Arecaceae, Bignoniaceae and Moraceae (each 7 species), while 17 families represented by just single species' each in study area. Of 99 species, 43 species each recorded under not evaluated and least concern, 8 in vulnearble, 2 each in data deficient and endangered, and just one in near threatened categories of IUCN's Red List (Figure 2). Seven species namely, Canthium dicoccum, Chloroxylon swietenia, Delonix regia, Khaya senegalensis, Pterocarpus marsupium, Saraca asoca and Swietenia macrophylla were recorded as vulnerable in IUCN's Red List, while the remaining three species Guaiacum officinale, Pterocarpus santalinus and Swietenia mahagoni were found as endangered (Table 2).

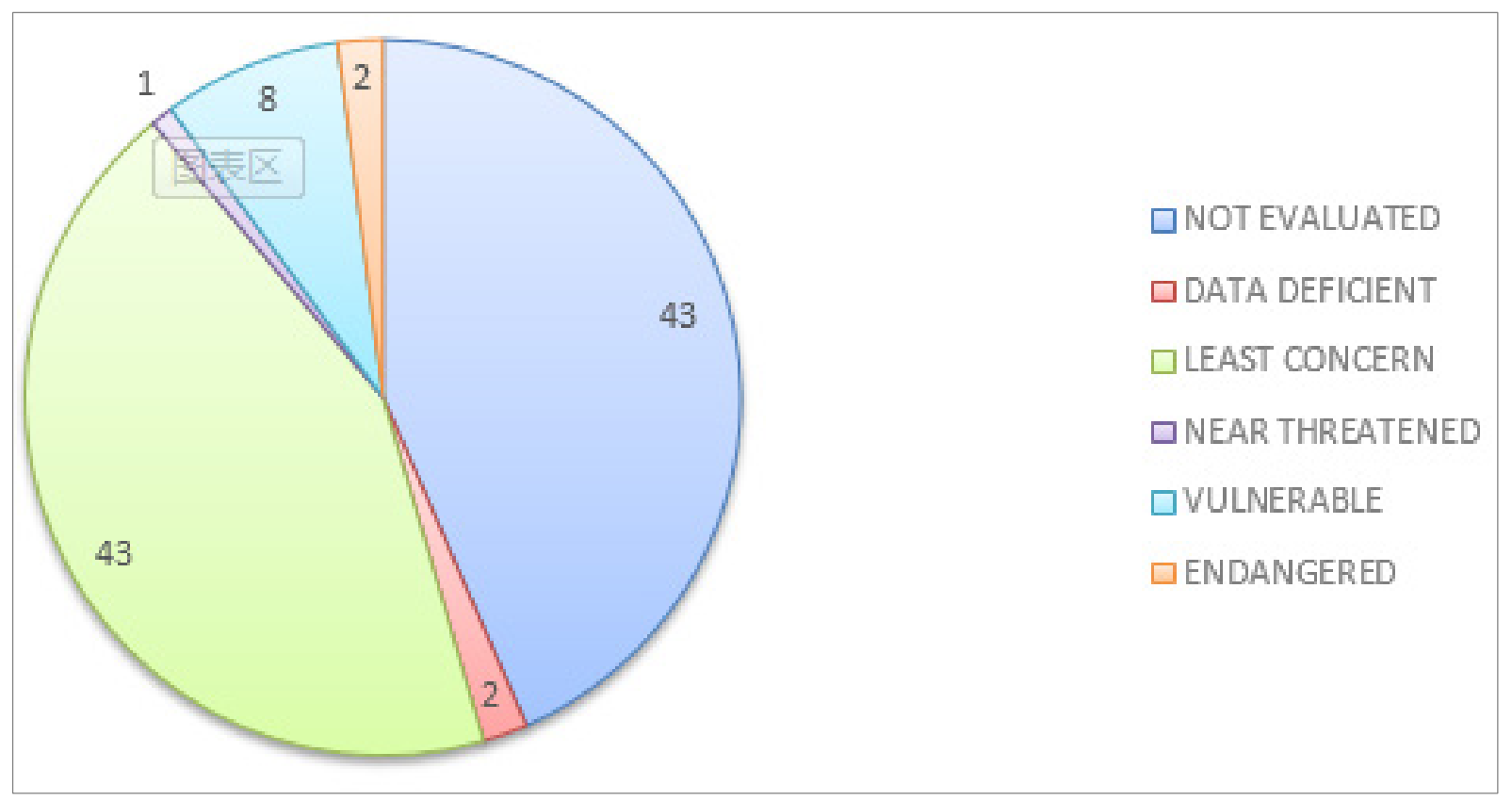

Figure 1. Proportion of trees categorized based on IUCN threat status 
Table 2. Botanical name, family, density and IUCN categories of trees recorded in Chennai metropolitan city, India (NE: Not Evaluated, DD: Data Deficient, LC: Least concern, NT: Near Threatened, VU: Vulnerable, EN: Endangered)

\begin{tabular}{|c|c|c|c|}
\hline Botanical name & Family & Density & IUCN category \\
\hline 1. Acacia auriculiformis A.Cunn. ex Benth. & Fabaceae & 15 & $\mathrm{LC}$ \\
\hline 2. Adenanthera pavonina $\mathrm{L}$. & Fabaceae & 65 & $\mathrm{LC}$ \\
\hline 3. Alangium salviifolium (L.f.) Wangerin. & Cornaceae & 5 & $\mathrm{LC}$ \\
\hline 4. Albizia saman (Jacq.) F.Muell. & Fabaceae & 430 & NE \\
\hline 5. Albizia lebbeck (L.) Benth. & Fabaceae & 27 & NE \\
\hline 6. Alstonia scholaris (L.) R. Br. & Apocynaceae & 17 & $\mathrm{LC}$ \\
\hline 7. Annona squamosa $\mathrm{L}$. & Annonaceae & 15 & $\mathrm{LC}$ \\
\hline 8. Artocarpus heterophyllus Lam. & Moraceae & 31 & NE \\
\hline 9. Azadirachta indica A. Juss. & Meliaceae & 215 & $\mathrm{LC}$ \\
\hline 10. Bauhinia racemosa Lam. & Fabaceae & 27 & NE \\
\hline 11. Bixa orellana L. & Bixaceae & 5 & $\mathrm{LC}$ \\
\hline 12. Bombax ceiba $\mathrm{L}$. & Bombacaceae & 23 & NE \\
\hline 13. Borassus flabellifer $\mathrm{L}$. & Arecaceae & 27 & NE \\
\hline 14. Butea monosperma (Lam.) Taub. & Fabaceae & 7 & $\mathrm{NE}$ \\
\hline 15. Caesalpinia coriaria (Jacq.) Willd. & Fabaceae & 35 & $\mathrm{NE}$ \\
\hline 16. Caesalpinia pulcherrima (L.) Sw. & Fabaceae & 37 & $\mathrm{LC}$ \\
\hline 17. Callistemon citrinus (Curtis) Stapf. & Myrtaceae & 10 & $\mathrm{NE}$ \\
\hline 18. Calophyllum inophyllum $\mathrm{L}$. & Clusiaceae & 13 & $\mathrm{LC}$ \\
\hline 19. Canthium dicoccum (Gaertn.) Merr. & Rubiaceae & 52 & VU \\
\hline 20. Carica papaya $\mathrm{L}$. & Caricaceae & 52 & $\mathrm{DD}$ \\
\hline 21. Caryota urens L. & Arecaceae & 13 & $\mathrm{LC}$ \\
\hline 22. Cassia fistula $\mathrm{L}$. & Fabaceae & 57 & $\mathrm{LC}$ \\
\hline 23. Cassia roxburghii DC. & Fabaceae & 62 & NE \\
\hline 24. Cassia siamea Lam. & Fabaceae & 27 & $\mathrm{LC}$ \\
\hline 25. Casuarina equisetifolia $\mathrm{L}$. & Casuarinaceae & 65 & $\mathrm{LC}$ \\
\hline 26. Chloroxylon swietenia DC. & Rutaceae & 6 & VU \\
\hline 27. Chrysalidocarpus lutescens H.Wendl. & Arecaceae & 75 & NT \\
\hline 28. Cocos nucifera $\mathrm{L}$. & Arecaceae & 765 & $\mathrm{LC}$ \\
\hline 29. Cordia obliqua Willd. & Boraginaceae & 198 & NE \\
\hline 30. Cordia sebestena $\mathrm{L}$. & Boraginaceae & 76 & $\mathrm{LC}$ \\
\hline 31. Couroupita guianensis Aubl. & Lecythidaceae & 5 & $\mathrm{LC}$ \\
\hline 32. Crateva magna (Lour.) DC. & Capparidaceae & 5 & $\mathrm{LC}$ \\
\hline 33. Crescentia cujete $\mathrm{L}$. & Bignoniaceae & 5 & $\mathrm{LC}$ \\
\hline 34. Dalbergia coromandeliana Prain & Papilionaceae & 2 & NE \\
\hline 35. Delonix regia (Bojer ex Hook.) Raf. & Fabaceae & 1002 & VU \\
\hline 36. Diospyros peregrina Gurke & Ebenaceae & 3 & NE \\
\hline 37. Erythrina variegata $\mathrm{L}$. & Fabaceae & 15 & $\mathrm{LC}$ \\
\hline 38. Eucalyptus globulus Labill. & Myrtaceae & 51 & $\mathrm{LC}$ \\
\hline 39. Ficus benghalensis L. & Moraceae & 15 & NE \\
\hline 40. Ficus elastica Roxb. & Moraceae & 5 & NE \\
\hline 41. Ficus racemosa L. & Moraceae & 21 & $\mathrm{LC}$ \\
\hline 42. Ficus religiosa $\mathrm{L}$. & Moraceae & 33 & NE \\
\hline 43. Ficus tomentosa $\mathrm{L}$. & Moraceae & 3 & NE \\
\hline 44. Glricidia sepium (Jacq.) Kunth & Fabaceae & 47 & $\mathrm{LC}$ \\
\hline 45. Gmelina arborea Roxb. & Verbenaceae & 51 & $\mathrm{LC}$ \\
\hline 46. Guaiacum officinale L. & Zygophyllaceae & 9 & EN \\
\hline 47. Guazuma ulmifolia Lam. & Sterculiaceae & 297 & $\mathrm{LC}$ \\
\hline 48. Hibiscus tiliaceus L. & Malvaceae & 32 & $\mathrm{LC}$ \\
\hline 49. Ixora pavetta Andrews & Rubiaceae & 15 & NE \\
\hline
\end{tabular}


Table 2 Continued

\begin{tabular}{|c|c|c|c|}
\hline 50. Khaya senegalensis (Desv.) A.Juss. & Meliaceae & 11 & $\mathrm{VU}$ \\
\hline 51. Kigelia africana (Lam.) Benth. & Bignoniaceae & 105 & $\mathrm{LC}$ \\
\hline 52. Lannea coromandelica (Houtt.) Merr. & Anacardiaceae & 205 & $\mathrm{NE}$ \\
\hline 53. Lawsonia inermis $\mathrm{L}$. & Lythraceae & 18 & $\mathrm{NE}$ \\
\hline 54. Leucaena latisiliqua (L.) Gillis \& Stearn & Fabaceae & 787 & $\mathrm{NE}$ \\
\hline 55. Limonia acidissima $\mathrm{L}$. & Rutaceae & 27 & $\mathrm{NE}$ \\
\hline 56. Livistona chinensis $\mathrm{R} . \mathrm{Br}$. & Arecaceae & 15 & $\mathrm{NE}$ \\
\hline 57. Madhuca longifolia (J. König ex L.) J.F. Macbr. & Sapotaceae & 65 & $\mathrm{NE}$ \\
\hline 58. Mangifera indica $\mathrm{L}$. & Anacardiaceae & 55 & $\mathrm{DD}$ \\
\hline 59. Markhamia stipulata Seem. & Bignoniaceae & 19 & $\mathrm{LC}$ \\
\hline 60. Millingtonia hortensis L.f. & Bignoniaceae & 112 & $\mathrm{NE}$ \\
\hline 61. Mimusops elengi $\mathrm{L}$. & Sapotaceae & 139 & LC \\
\hline 62. Morinda coreia Buch. -Ham. & Rubiaceae & 187 & $\mathrm{NE}$ \\
\hline 63. Moringa oleifera Lam. & Moringaceae & 22 & $\mathrm{NE}$ \\
\hline 64. Nerium oleander $\mathrm{L}$. & Apocynaceae & 85 & LC \\
\hline 65. Nyctanthes arbor-tristis $\mathrm{L}$. & Oleaceae & 56 & $\mathrm{NE}$ \\
\hline 66. Ochna serrata $\mathrm{L}$. & Ochnaceae & 11 & $\mathrm{NE}$ \\
\hline 67. Peltophorum pterocarpum (DC.) Baker ex. K.Heyne & Fabaceae & 532 & $\mathrm{NE}$ \\
\hline 68. Phoenix sylvestris (L.) Roxb. & Arecaceae & 10 & $\mathrm{NE}$ \\
\hline 69. Phyllanthus acidus (L.) Skeels & Euphorbiaceae & 55 & $\mathrm{NE}$ \\
\hline 70. Phyllanthus emblica L. & Euphorbiaceae & 35 & $\mathrm{NE}$ \\
\hline 71. Pisonia alba Span. & Nyctaginaceae & 27 & $\mathrm{NE}$ \\
\hline 72. Pithecellobium dulce (Roxb.) Benth. & Fabaceae & 15 & $\mathrm{LC}$ \\
\hline 73. Polyalthia longifolia (Sonn.) Thwaites & Annonaceae & 1150 & $\mathrm{NE}$ \\
\hline 74. Pongamia pinnata (L.) Merr. & Fabaceae & 513 & $\mathrm{LC}$ \\
\hline 75. Premna latifolia Roxb. & Verbenaceae & 5 & $\mathrm{NE}$ \\
\hline 76. Prosopis juliflora (Sw.) DC. & Fabaceae & 612 & $\mathrm{NE}$ \\
\hline 77. Psidium guajava $\mathrm{L}$. & Myrtaceae & 32 & $\mathrm{LC}$ \\
\hline 78. Pterocarpus marsupium Roxb. & Fabaceae & 20 & $\mathrm{VU}$ \\
\hline 79. Pterocarpus santalinus L.f. & Fabaceae & 10 & EN \\
\hline 80. Pterospermum canescens Roxb. & Sterculiaceae & 2 & $\mathrm{NE}$ \\
\hline 81. Punica granatum $\mathrm{L}$. & Lythraceae & 15 & $\mathrm{LC}$ \\
\hline 82. Roystonea regia (Kunth.) O.F.Cook. & Arecaceae & 32 & $\mathrm{NE}$ \\
\hline 83. Saraca asoca (Roxb.) De Wilde & Caesalpiniaceae & 55 & $\mathrm{VU}$ \\
\hline 84. Spathodea campanulata P.Beauv. & Bignoniaceae & 184 & $\mathrm{LC}$ \\
\hline 85. Sterculia foetida $\mathrm{L}$. & Sterculiaceae & 112 & $\mathrm{NE}$ \\
\hline 86. Streblus asper Lour. & Moraceae & 15 & $\mathrm{LC}$ \\
\hline 87. Swietenia macrophylla King. & Meliaceae & 55 & $\mathrm{VU}$ \\
\hline 88. Swietenia mahagoni $\mathrm{L}$. & Meliaceae & 52 & $\mathrm{VU}$ \\
\hline 89. Syzygium cumini (L.) Skeels & Myrtaceae & 97 & LC \\
\hline 90. Tabebuia rosea DC. & Bignoniaceae & 165 & $\mathrm{LC}$ \\
\hline 91. Tamarindus indica $\mathrm{L}$. & Fabaceae & 65 & $\mathrm{LC}$ \\
\hline 92. Tecoma stans (L.) Kunth. & Bignoniaceae & 97 & $\mathrm{NE}$ \\
\hline 93. Terminalia arjuna Wight \& Arn. & Combretaceae & 13 & $\mathrm{NE}$ \\
\hline 94. Terminalia bellirica (Gaertn.) Roxb. & Combretaceae & 11 & $\mathrm{NE}$ \\
\hline 95. Terminalia catappa $\mathrm{L}$. & Combretaceae & 106 & $\mathrm{LC}$ \\
\hline 96. Thespesia populnea (L.) Sol. ex Corrêa & Malvaceae & 56 & $\mathrm{LC}$ \\
\hline 97. Vitex altissima $\mathrm{L}$. f. & Verbenaceae & 1 & LC \\
\hline 98. Wrightia tinctoria R. Br. & Apocynaceae & 112 & LC \\
\hline \multirow[t]{2}{*}{ 99. Ziziphus mauritiana Lam. } & Rhamnaceae & 178 & LC \\
\hline & Total & 10426 & \\
\hline
\end{tabular}




\subsection{Density}

Density of trees $(\geq 10 \mathrm{~cm}$ gbh) varied considerably across land use categories. The riverbanks recorded highest tree density $\left(150.08 \pm 21.02\right.$ trees $\left.\mathrm{ha}^{-1}\right)$ followed by parks $\left(138.86 \pm 29.08\right.$ trees $\left.\mathrm{ha}^{-1}\right)$ and educational institutions $\left(98.77 \pm 4.48\right.$ trees $\left.\mathrm{ha}^{-1}\right)$, while roadsides had the least tree density $\left(61.69 \pm 6.72\right.$ trees $\left.^{-1}{ }^{-1}\right)$ in CMC (Table 3).

The mean tree density of study area was $104.26 \pm 36.13$ trees ha ${ }^{-1}$. The average tree density ha ${ }^{-1}$ recorded is more or less equal to urban forests of Oakland, USA (111.9 trees $\mathrm{ha}^{-1}$ ), while it is lesser than urban forests of ten USA cities $\left(147\right.$ trees ha $\left.{ }^{-1}\right)[23]$, Miami-Dade county $\left(235\right.$ trees ha $\left.^{-1}\right)$ [24], urban forests of New Delhi, India (228 trees ha $\left.{ }^{-1}\right)$ [25] and Nagoya, Japan (2852 trees $\mathrm{ha}^{-1}$ ) [26]. However, the mean tree density ha ${ }^{-1}$ found in this study is higher than that of what has been reported for urban forests ( 45.6 trees $\mathrm{ha}^{-1}$ ) [27] and parks (47.5 trees $\left.\mathrm{ha}^{-1}\right)$ of Bangalore, India [28]; Sacramento, USA (73 trees ha ${ }^{-1}$ ) [29]; and Beijing, China $\left(79\right.$ trees ha $\left.{ }^{-1}\right)[30]$.

In total, institutional areas support highest number of threatened trees ( 374 trees) followed by parks (327 trees) and residential areas (228 trees), while riverbanks had just 15 trees in 13.234 hectare area. Total number of each threatened species varied across land uses. For example,
Delonix regia represented with 282 individuals in parks while riverbanks had just 15 individuals (Table 4). Of 10 threatened species, nine (except Delonix regia) represented by large number of individuals in institutional areas, whereas $D$. regia represented abundantly in residential areas than the other land uses. Similarly, institutional areas had all the 10 threatened species, while riverbanks had just single threatened species.

Generally, stakeholders of institutional areas have awareness on importance of biodiversity and threatened species. In addition, academic institutions have protected environment than the other land use categories and hence harbors all the 10 threatened species. Metropolitan authorities protect urban parks and trees on roadsides from anthropogenic damages. Local people grow trees not only for shade but also to enhance the aesthetic values of buildings and living places. Riverbanks of Cooum and Adyar are highly polluted by unhealthy human activities as is evident from the presence of invasive alien species on riverbanks [31]. Two tropical American species (Prosopis juliflora - Fabaceae and Muntingia calabura Muntingiaceae) dominate riverbanks in CMC. Thus, only 15 threatened trees are occurring in 13.234 ha area of riverbanks.

Table 3. The mean (no. ha ${ }^{-1}$ ) and total number of trees documented in study area

\begin{tabular}{|c|c|c|c|}
\hline Site & Density of all trees (no. ha-1) mean \pm S.D. & Total no. of trees & $\begin{array}{c}\text { Number of threatened trees in } \\
\text { study area* }\end{array}$ \\
\hline Educational institutions & $98.77 \pm 4.48$ & 2173 & 374 \\
\hline Riverbanks & $150.08 \pm 21.02$ & 1951 & 327 \\
\hline Parks & $138.86 \pm 29.08$ & 3055 & 165 \\
\hline Roadsides & $61.69 \pm 6.72$ & 987 & 228 \\
\hline Residential areas & $70.05 \pm 5.30$ & 1471 & 163 \\
\hline Government offices & $87.67 \pm 5.61$ & 789 & 1272 \\
\hline
\end{tabular}

*Threatened trees include both vulnerable and endangered tree species

Table 4. Number of threatened trees encountered in different land use categories in Chennai metropolitan city, India

\begin{tabular}{|c|c|c|c|c|c|c|}
\hline & \multicolumn{6}{|c|}{ Number of threatened trees } \\
\hline Species & Institutions & Riverbanks & Parks & Roadsides & Residential areas & Government offices \\
\hline Delonix regia & 231 & 15 & 282 & 152 & 188 & 134 \\
\hline Saraca asoca & 25 & - & 12 & 5 & 6 & 7 \\
\hline Swietenia macrophylla & 28 & - & 6 & 2 & 12 & 7 \\
\hline Swietenia mahagoni & 21 & - & 9 & 2 & 15 & 5 \\
\hline Canthium dicoccum & 40 & - & 12 & - & - & - \\
\hline Pterocarpus marsupium & 11 & - & 3 & - & 4 & 2 \\
\hline Khaya senegalensis & 6 & - & - & 1 & 2 & 2 \\
\hline Pterocarpus santalinus & 4 & - & 3 & 1 & - & 2 \\
\hline Guaiacum officinale & 6 & - & - & 1 & - & 2 \\
\hline \multirow[t]{2}{*}{ Chloroxylon swietenia } & 2 & - & - & 1 & 1 & 2 \\
\hline & 374 & 15 & 327 & 165 & 228 & 163 \\
\hline
\end{tabular}




\subsection{Diversity}

Shannon diversity index $(H)$ recorded in study area $(H=$ 3.6) is very well within the range compared with those of urban forests in the USA ( mean $=2.7$; range $=2.1-3.9)$ [32]. However, the present study area had a little higher Shannon index value compared to urban forests of Bangalore Metropolitan City $(H=2.68)[26,27]$ and Miami-Dade County of USA $(H=0.58)$ [24]. Similarly, Shannon equitability index $\left(\mathrm{E}_{\mathrm{H}}=0.78\right)$ computed for study area is also higher than in Miami-Dade County of USA $\left(E_{H}=0.6\right)$. The top ten species constituted $60.29 \%$ of tree community in study area; remaining 89 species together formed only $39.71 \%$ tree community. The unequal contribution of species to tree community in study area produced less evenness.

\subsection{Density and Diversity of Threatened Species}

A total of 1272 threatened tree individuals belonging to six families and seven genera were recorded in 100 ha study area. Density and frequency of threatened species varied considerably in study area. Among 10426 trees, 1272 were found in threatened categories of IUCN's Red List - 2012. Of 1272 trees 74 belonged to endangered category of Red List, remaining 1198 individuals fell under vulnerable category. Of seven vulnerable species, Delonix regia had highest number of individuals (1002 trees) in study area followed by Saraca asoca and Swietenia macrophylla (each 55 individuals), while Chloroxylon swietenia represented with just six individuals (Table 5). Of 100 study plots, vulnerable tree species Delonix regia recorded in 97 plots, Saraca asoca found in 49 plots, Swietenia macrophylla encountered in 42 plots. The endangered species Swietenia mahagoni recorded in 47 plots, while Chloroxlon swietenia found in just five study plots (Table 5).

Earlier, urban forests have been recognised as habitats for endangered species. Urban green areas of Sweden harbor endangered tree species [3]. The thickly populated Stockholm County had two-thirds of red-listed species [33]. Gustaffson [34] found red-listed species such as Dryopteris cristata and Buxbaumia viridis in urban forests of Stockholm. Similarly, the highly populated Cook County of Chicago metropolitan area is recognised as a home for 130 endangered plant species [35].

The local people and foresters favour Delonix regia (Royal Poinciana) for its beautiful flowers, fruits and fast growth. These days, the urban forest division of Tamil Nadu forest department distributes evergreen tree species such as Saraca asoca, Swietenia macrophylla, Pterocarpus marsupium and Khaya senegalensis to enhance green cover in Chennai city. Chloroxylon swietenia, Canthium diccoccum and Pterocarpus santalinus are representing the local forest type i.e., tropical dry evergreen forest $[14,16$, 36].

Table 5. Threatened category, density and frequency of trees recorded in study area

\begin{tabular}{|c|c|c|c|c|}
\hline Species & Family & Threatened category (IUCN Red List - 2012) & Density & Frequency \\
\hline Canthium dicoccum & Rubiaceae & Vulnerable & 52 & 19 \\
\hline Chloroxylon swietenia & Rutaceae & Vulnerable & 1002 & 5 \\
\hline Delonix regia & Caesalpiniaceae & Vulnerable & 9 & 97 \\
\hline Guaiacum officinale & Zygophyllaceae & Endangered & 11 & 10 \\
\hline Khaya senegalensis & Meliaceae & Vulnerable & 20 & 15 \\
\hline Pterocarpus marsupium & Fabaceae & Vulnerable & 10 & 8 \\
\hline Pterocarpus santalinus & Fabaceae & Endangered & 55 & 49 \\
\hline Saraca asoca & Caesalpiniaceae & Vulnerable & 52 & 47 \\
\hline Swietenia mahagoni & Meliaceae & Endangered & 55 & 42 \\
\hline Swietenia macrophylla & Meliaceae & Vulnerable & 1272 & - \\
\hline
\end{tabular}




\subsection{Population Structure}

In total, tree community of the study area showed a typical expanding population structure. The smallest girth class had the highest number of individuals, while the largest girth class had the least number of trees (Figure 3). However, the population structure of threatened species varied considerably. Among 10 threatened species, four species namely, Canthium dicoccum, Delonix regia, Saraca asoca and Swietenia macrophylla showed expanding population structure (Figure 4). The remaining six species had disturbed population structure in study area (Figure 5). For example, the indigenous species
Chloroxylon swietenia had just three individuals each in 90.1-120 and 120.1-150 cm gbh. To ensure continuous presence of species in a community, the species should possess considerable number of individuals in all the girth classes. If a species' does not possess viable population then gradually it would lose its place from the community $[37,38]$. Planting saplings of threatened species in appropriate places could improve the population structure of trees thereby urban forest of Chennai could serve as a habitat for more number of vulnerable and endangered tree species in the near future.

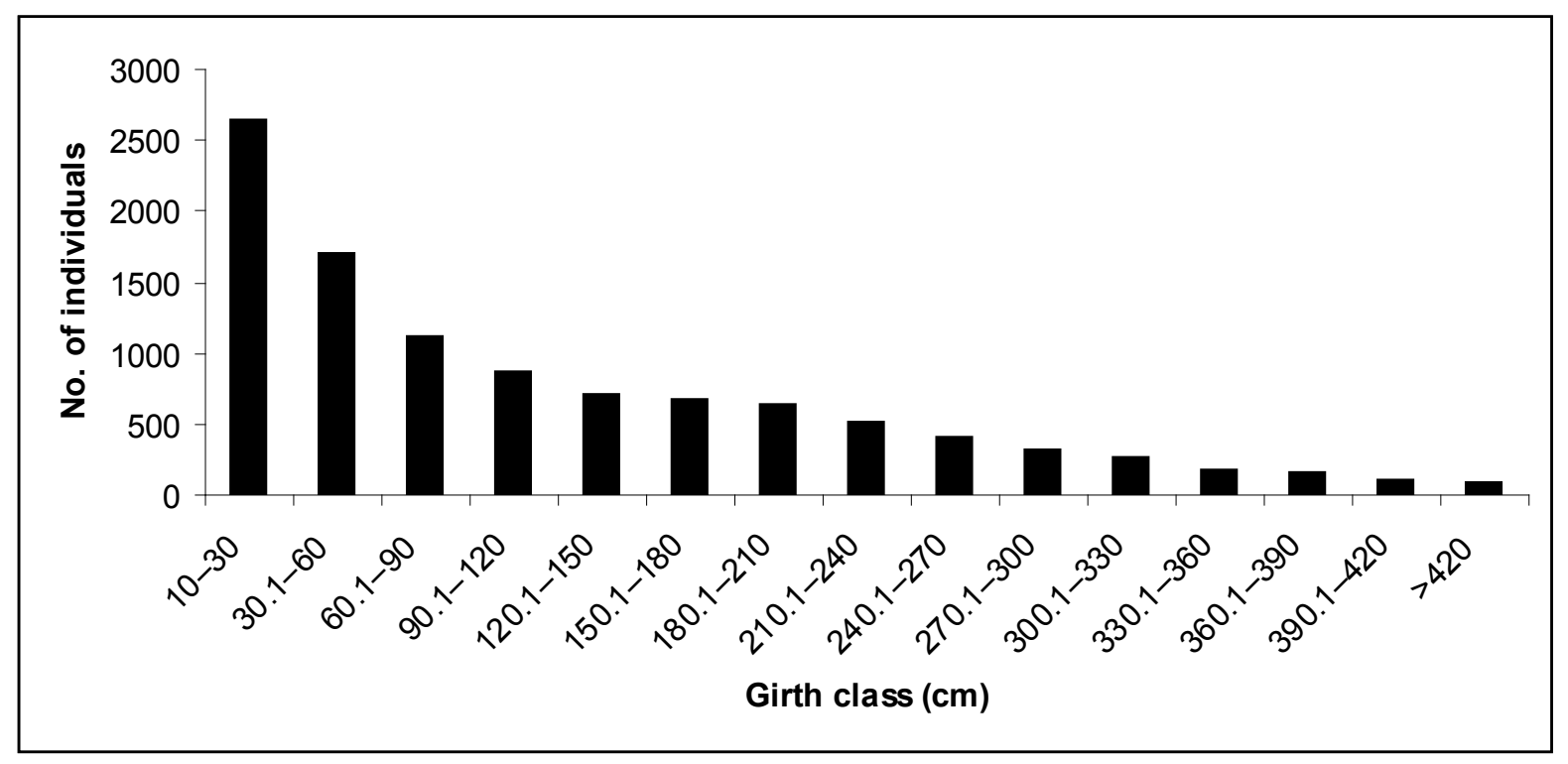

Figure 3. Stand structure of trees based on girth class frequency in study area.

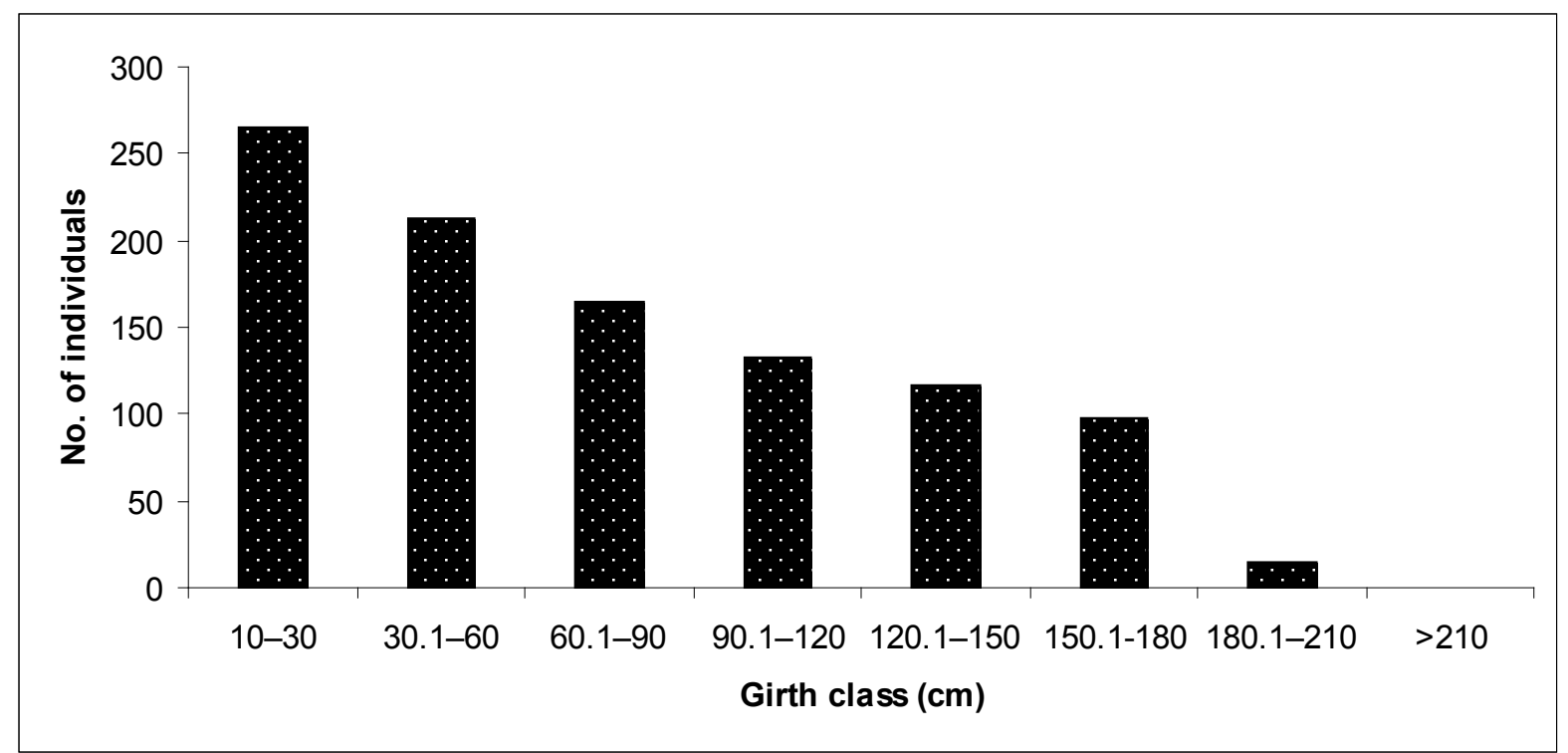

Figure 4. Population structure of Delonix regia based on girth class frequency in study area 


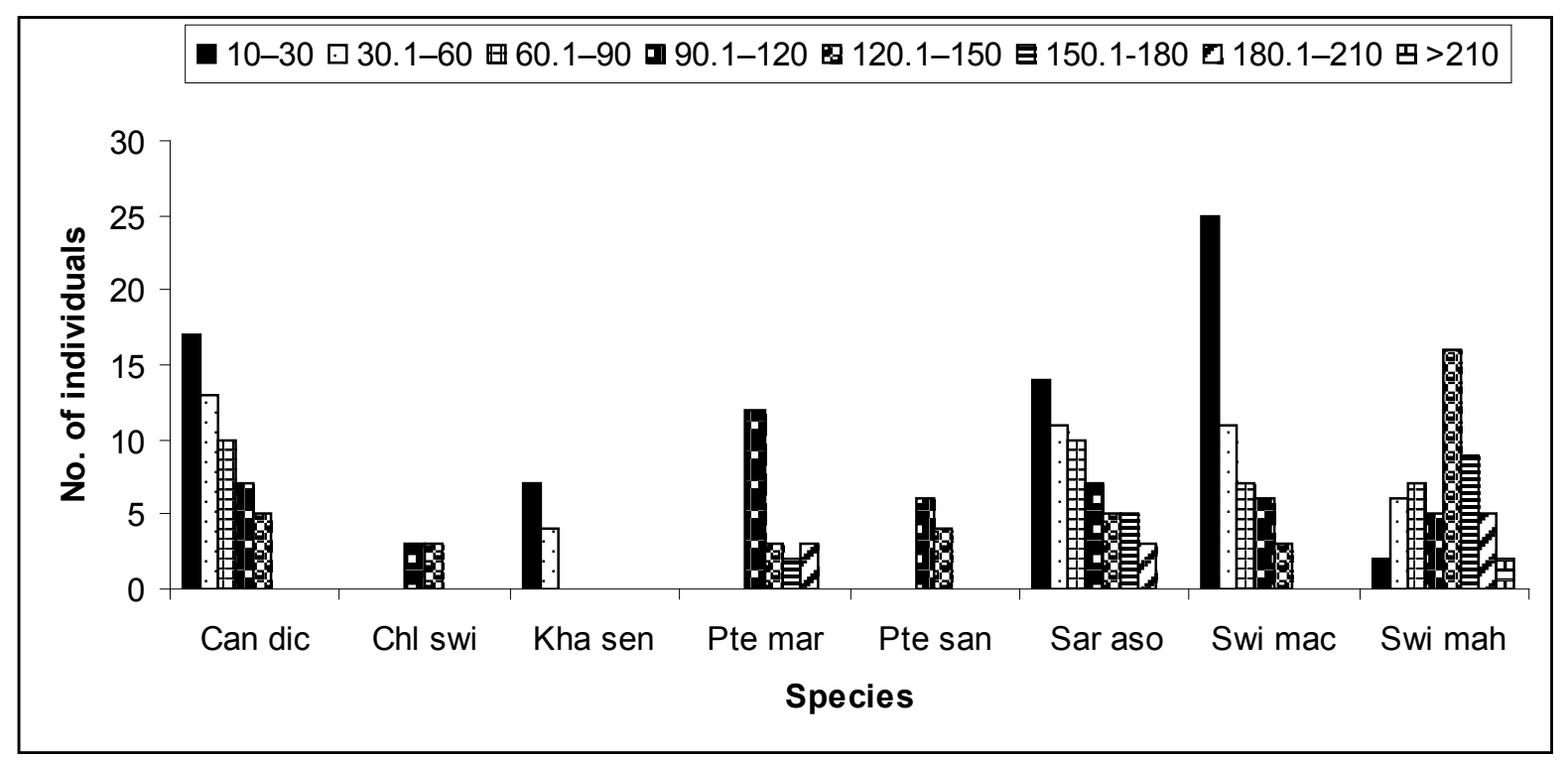

Figure 5. Population structure of threatened species based on girth class frequency in Chennai metropolitan city, India

\section{Conclusions}

We find Chennai's urban forest as home for 10 IUCN's red-listed tree species. Present study recorded density and population structure of threatened trees in 100 ha area of CMC. Further, studies with larger study areas are essential to record the total density and species richness of threatened trees in the entire area of CMC. The Government should provide financial support to researchers to document the essential baseline data on threatened species. In addition, as mentioned in earlier literatures [39-42] dissemination of information about threatened species is essential to preserve the precious natural resource in human dominated CMC, India.

\section{Acknowledgements}

The first author MU thank the Science and Engineering Research Board for providing fellowship under Young Scientist Scheme (File No. YSS/2015/002008 dt. 31.05.2016).

\section{REFERENCES}

[1] C.D. Ward, C. M. Parker, C. M. Shackleton. The use and appreciation of botanical gardens as urban green spaces in South Africa. Urban Forestry \& Urban Greening, 9(1): 49-55, 2010.

[2] A.A. Alvey. Promoting and preserving biodiversity in the urban forest. Urban Forestry \& Urban Greening, 5(4): 195-201, 2006.

[3] W.M. Kaerkes. Zur ökologischen Bedeutung urbaner
Freiflächen: dargestellt an Beispielen aus dem mittleren Ruhrgebiet. Geograph. Inst., Ruhr-Univ. Bochum, 1987.

[4] A. Balmford, J. L. Moore, T. Brooks, N. Burgess, L. A. Hansen, P. Williams, C. Rahbek. Conservation conflicts across Africa. Science, 291(5513): 2616-2619, 2001.

[5] C. Jim, H. Liu. Species diversity of three major urban forest types in Guangzhou City, China. Forest Ecology and Management, 146(1): 99-114, 2001.

[6] J. Cornelis, M. Hermy M. Biodiversity relationships in urban and suburban parks in Flanders. Landscape and Urban Planning, 69(4): 385-401, 2004.

[7] I. Kühn, R. Brandl, S. Klotz. The flora of German cities is naturally species rich. Evolutionary ecology research, 6(5): 749-764, 2004.

[8] H. Sukopp, R. Wittig. In: H. Sukopp, R. Wittig (eds.). Stadtökologie. Gustav Fischer Verlag, Stuttgart, 402 pp. 1993.

[9] R. Witting. Siedlungsvegetation, Verlag Eugen Ulmer, Stuttgart, 252 pp, 2002.

[10] R. A. Shepherd. A review of plant communities of derelict land in the city of Nottingham, England and their value for nature conservation. Memorabilia Zoologica, (49), 1994.

[11] B. C. Eversham, D. B. Roy, M.G. Telfer. Urban, industrial and other manmade sites as analogues of natural habitats for Carabidae. In: Annales Zoologici Fennici, Finnish Zoological and Botanical Publishing Board, p. 149-156, 1996.

[12] C. S. Holling, G. K. Meffe. Command and control and the pathology of natural resource management. Conservation biology, 10(2): 328-337, 1996.

[13] N. S. Sodhi, T. M. Lee, L. P. Koh, D. M. Prawiradilaga. Long - Term Avifaunal Impoverishment in an Isolated Tropical Woodlot. Conservation Biology, 20(3): 772-779, 2006. 
[14] U. Muthulingam, S. Thangavel. Density, diversity and richness of woody plants in urban green spaces: A case study in Chennai metropolitan city. Urban Forestry \& Urban Greening, 11(4): 450-459, 2012.

[15] B. Thaiutsa, L. Puangchit, R. Kjelgren, W. Arunpraparut. Urban green space, street tree and heritage large tree assessment in Bangkok, Thailand. Urban Forestry \& Urban Greening, 7(3): 219-229, 2008.

[16] M. Udayakumar, M. Ayyanar, T. Sekar. Angiosperms, Pachaiyappa's College, Chennai, Tamil Nadu, India. Check List, 7(1): 37-48, 2011.

[17] P. Nehru, G. Gnanasekaran, N. M. Karthick, D. Narasimhan. Angiosperms of Nanmangalam Reserve Forest, an urban forest in Metropolitan Chennai, India. Check List, 8(1): 057-076, 2012.

[18] Climate and Weather of Chennai Metropolitan [http://www. chennaidistrict/tn.nic.in.]

[19] Master plan-II for Chennai Metropolitan Area-2026, [http://www.cmdachennai.gov.in]

[20] J. Gamble, C. E. C. Fischer. Flora of the Presidency of Madras. Vols I-III, Adlard \& Co, London, 1915-1935.

[21] IUCN: Red List of Threatened Species, Version 2012.1.

[22] A. E. Magurran. Ecological Diversity and its Measurement, Princeton University Press. New Jersey, 1988.

[23] D. J. Nowak, D. E. Crane. Carbon storage and sequestration by urban trees in the USA. Environmental pollution, 116(3): 381-389, 2002.

[24] M. Zhao, F. J. Escobedo, C. Staudhammer. Spatial patterns of a subtropical, coastal urban forest: Implications for land tenure, hurricanes, and invasives. Urban Forestry \& Urban Greening, 9(3): 205-214, 2010.

[25] N. Khera, V. Mehta, B. Sabata. Interrelationship of birds and habitat features in urban greenspaces in Delhi, India. Urban Forestry \& Urban Greening, 8(3): 187-196, 2009.

[26] M. Awal, T. Ohta, K. Matsumoto, T. Toba, K. Daikoku, S. Hattori, T. Hiyama, H. Park. Comparing the carbon sequestration capacity of temperate deciduous forests between urban and rural landscapes in central Japan. Urban Forestry \& Urban Greening, 9(3): 261-270, 2010.

[27] H. Nagendra, D. Gopal. Street trees in Bangalore: Density, diversity, composition and distribution. Urban Forestry \& Urban Greening, 9(2): 129-137, 2010.

[28] H. Nagendra, D. Gopal. Tree diversity, distribution, history and change in urban parks: studies in Bangalore, India. Urban Ecosystems, 14(2): 211-223, 2011.

[29] R. A. Birdsey, L. S. Heath. Carbon changes in U.S. forests. In: Productivity of America's Forests and Climate Change,
General Technical Report RM-GTR-271, USA. Edited by L. A. Joyce, USDA Forest Service, Rocky Mountain Forest and Range Experiment Station, 56-70, 1995.

[30] J. Yang, J. McBride, J. Zhou, Z. Sun. The urban forest in Beijing and its role in air pollution reduction. Urban Forestry \& Urban Greening, 3(2): 65-78, 2005.

[31] P. V. Mayuranathan. The flowering plants of Madras city and its immediate neighbourhood, In: Bulletin of the Madras government museum. Madras Government Press, Madras, India, 1929.

[32] E. G. McPherson, D. Nowak, G. Heisler, S. Grimmond, C. Souch, R. Grant, R. Rowntree. Quantifying urban forest structure, function, and value: The Chicago Urban Forest Climate Project. Urban ecosystems, 1(1): 49-61, 1997.

[33] L. Gustafsson. Presence and abundance of red - listed plant species in Swedish forests. Conservation Biology, 16(2): 377-388, 2002.

[34] J. Colding, T. Elmqvist, J. Lundberg, K. Ahrné, E. Andersson, S. Barthel, S. Borgström, A. Duit, H. Ernstsson, M. Tengö. The Stockholm Urban Assessment (SUA-Sweden). Millennium Ecosystem Assessment Sub-Global Summary Report, Stockholm. 2003.

[35] W. L. Howenstine. Urban forests as part of the whole ecosystem. In: 6th National Urban Forestry Conference, Washington, DC, American Forests, pp. 118-120, 1993.

[36] M. Udayakumar, N. Parthasarathy. Angiosperms, tropical dry evergreen forests of southern Coromandel coast, India. Check List, 6(3): 368-381, 2010.

[37] D. H. Janzen. Guanacaste National Park: tropical ecological and cultural restoration (No. AS 50907). Fundacion Tinkes, New York (EUA) FPN, San Jose (Costa Rica), 1986.

[38] P. J. Donoso, R. D. Nyland. Seedling density according to structure, dominance and understory cover in old-growth forest stands of the evergreen forest type in the coastal range of Chile. Revista Chilena de Historia Natural, 78(1): 51-63, 2005.

[39] T. Kendle, F. Stephen. Urban Nature Conservation: landscape management in the urban countryside, Taylor \& Francis, 1997.

[40] P. Clergeau, J. Jokimäki, J. P. L. Savard. Are urban bird communities influenced by the bird diversity of adjacent landscapes? Journal of Applied Ecology, 38(5): 1122-1134, 2001.

[41] S. R. Mehmood, D. Zhang. A roll call analysis of the Endangered Species Act amendments. American Journal of Agricultural Economics, 83(3): 501-512, 2001.

[42] J.R. Miller, R. J. Hobbs. Conservation where people live and work. Conservation biology, 16(2): 330-337, 2002. 